\title{
Common and distinctive features of higher education quality evaluation in Ukraine and France
}

\author{
A. P. Durdas \\ Senior Lecturer at the Department of Modern European Languages, Kyiv National University of Trade and Economics, Kyiv, \\ Ukraine \\ Corresponding author. E-mail: durdas@ukr.net ORCID: 0000-0001-6456-6108
}

Paper received 07.02.21; Accepted for publication 22.02.21.

\section{https://doi.org/10.31174/SEND-PP2021-247IX98-02}

Abstract. The article deals with common and distinctive features in evaluation of higher education quality in France and in Ukraine. The author has characterized and analyzed the peculiarities of work of higher education evaluation systems in both countries.

Keywords: higher education, evaluation, system of evaluation.

Introduction. Higher education is constantly changing and developing. Its development in France and Ukraine is influenced by policy priorities at the national and European levels, as well as other general factors such as demography, immigration, global and national economies, changing needs and dynamics of the labor market, digitalization, as well as internationalization and globalization. All of these factors influence institutional and national policies and strategies in higher education, and affect quality assurance systems and the work of external quality assurance bodies. The problem of the quality of higher education is particularly relevant today, in the context of the consolidation of the European higher education area, which makes it essential in the educational policy of the countries participating in the Bologna Process [5,6,7].

A brief overview of publications on the topic. Dozens of scientific sources cover various aspects of the higher education system in France and Ukraine. Among the authors we should mention the French scientists: L. Endrizzi [8], Stumpf A. [16], P.-A. Garessus [16], R. Colet [3], Hénard, F. [10] and the domestic researchers: Ye. Kananykina [12], S. Gordiychuk [9], A. Durdas [5, 6, 7], A. Kharkivska A. [13], N. Batechko [7], L. Belova [1] and others. However, a meaningful analysis of scientific works shows that despite a fairly active study of various aspects of the development of higher education in France, studies of the problem of assessing the quality of higher education in France and Ukraine in the context of European integration processes have not yet been analyzed comprehensively.

The purpose of the article is to study common and distinctive features in higher education quality evaluation in France and in Ukraine.

Materials and methods. To achieve the goal, we have analyzed the works of the Ukrainian and French researchers as well as official websites of the evaluation bodies. At the same time, various methods were used, in particular: theoretical, comparative-analytical, historical-structural, systemic, methods of generalization and systematization to study common and distinctive features of higher education quality evaluation.

Results and Discussion. The specific features of the system for evaluating the quality of higher education in France and Ukraine have been formed due to historical experience, national traditions, mentality of the population and economic development. As a result, we realize the need to carry out a comparative analysis of the systems for assessing the quality of university education in the two countries.
The modernization of the national education system in Ukraine is now taking place in the context of the development of our state as a European one. Especially significant transformations are to take place in vocational education, since the processes of globalization, integration and informatization of society cause profound civilizational changes that affect the requirements for specialists' professional training. In this context, the experience of France as a member of the European educational space and one of the initiators of the Bologna process, is of considerable interest.

It is worthwhile to analyze the ideas of the French researches regarding higher education quality. So, the French researcher L. Endrizzi emphasizes three interdependent levels of influence on the quality of education: educational institution, learning and individuals [8]. According to A. Stumpf and P.-A. Garessus, there is no consensus in the literature on how to define the quality of higher education or how to measure it [16]. However, the authors accept the fact that education quality is related to three objects: the development of quality culture, high-quality educational offer and support for teaching and learning [8; 10]. According to the French researcher R. Colet, since 1992 the process of disseminating teaching quality assessment in France has been marked by hesitations from the government's part, a sign of a political unwillingness of commotion caused by measures that undermine the values of profession or even require a construction of a new system of values [3].

It is necessary to note that the external evaluation system was formed in France in the mid-1980s. The University Committee (CNE) was created in 1984 and played a central role in the evaluation. It was an autonomous administrative entity that reported directly to the President of the Republic, and the mission was to evaluate universities, schools and other institutions in areas related to the missions of the public sector of higher education. AERES (Agency for Evaluation of Research and Higher Education) inherited this mission. [14].

Since the adoption of the Law on Finance Act (LOLF), the budget has been allocated on the basis of the performance of higher education establishments. In addition, in France, since 1996, universities have been required to conduct self-assessments of their educational programs, including surveys by students. Therefore, educational institutions have created specialized services called "observatories". These observatories collect data, conduct surveys and produce internal indicators for students and alumni in 
order to increase their own statistical and analytical capacity [14].

In France, the results of university examinations and evaluations are widely published, providing an opportunity not only for the state, but also for the public to make conclusions about the academic level of a higher educational establishment. This mechanism reflects the historically developed centralized system of French higher education. [14].

At the same time, the accreditation process under French ministries is increasingly associated with external evaluation of educational programs. Meanwhile, the Higher Education and Research Act requires each institution to create an internal self-assessment commission. Some universities include students to such commissions. In addition, the Network for Quality in Higher Education and Research, including French universities, promotes staff exchange and quality assurance [14].

As it has been noted above, in France, the government and higher education institutions make contracts every five years to implement the national strategy for higher education and research. As part of contracting goals, the government divided France into five geographic zones (A, B, C, $\mathrm{D}$ and $\mathrm{E}$ ) and implemented institutional accreditation (including approval of the establishment of a curriculum, certification and renewal of authority to award degrees). Thus, the system of contracts between the government, each institution and the accreditation are closely related, and since the enactment of the LOLF Law requires institutions to improve their practice, taking into consideration the assessment of performance and fulfillment of their accountability. The circumstances of the assessment seem to have moved from a culture of activities to a culture of results and performance. Under the new system, the authority of the management sector in the institutions was expanded, and this sector was given the authority to manage finances and personnel, as well as organizational reforms. At the same time, the government-controlled structure was reduced and university autonomy increased. Thus, the need arose for an independent evaluation of universities.

Today High Council for the Evaluation of Research and Higher Education (Hcéres) has a leading role in assessing higher education in France. It is important to note that the French government refers to the results of the Hcéres assessment when deciding whether to reinstate contracts for each institution and when making decisions on budget allocations, so these results have a significant impact.

Hcéres evaluates territorial coordination groups, universities, some universities, research institutions, educational programs and doctoral schools, without having the authority to make decisions on accreditation and funding. In doing so, Hcéres ensures sustainable improvement in the assessment process. [270, c. 33]. As for the system for assessing the quality of higher education in the French Republic, it is worth noting that the state system for assessing higher education in France provides for the presence of the so-called state quality mark, which is possessed by those universities that are recognized by the state. Higher schools, in which the Ministry of Public Education controls education, can issue diplomas "endorsed" by the ministry, which testifies, according to European concepts, to the quality of higher education. This "quality mark" is especially important, since only those diplomas that have such a state assessment are recognized in all European countries [12].

It is important to stress, that in France, in addition to the Hcéres, the evaluation of higher education quality is carried out by the following institutions:

Engineering Degree Commission (Commission des Titres d'Ingénieur, CTI) which evaluates programs for the training of future engineers.

the National Commission for the Evaluation of Training and Qualifications in Management (Commission d'évaluation des formations et diplômes de gestion, CEFDG) which establishes a quality management system for higher education in relation to business and management disciplines.

National Consultative Commission of IUT, CCNIUT (Commission consultative nationale des IUT, CCN$I U T$ ) which provides external quality assurance for university institutes of technology.

- General Inspectorate of the Administration of National Education and Research (Inspection générale de l'administration de l'éducation nationale et de la recherche, IGAENR). Its permanent mission is to monitor closely the functioning of the education system by monitoring it and providing it with the knowledge that would help to improve its functioning, supporting various subjects in the French education system from the national scale to the daily life of the classroom [1].

Ukraine is currently creating a national model of education quality management, which is based on the best world practices and meets the requirements of the International Organization for Standardization (ISO). [2]. As for the state of assessing the quality of higher education in Ukraine, we can note that the higher education system of Ukraine is at the stage of implementation of the Law of Ukraine dated 01.07.2014 No. 1556-VII "On Higher Education" and has an ambitious goal to meet the best international educational standards. According to the Law of Ukraine "On Higher Education", the quality assurance system for higher education in Ukraine consists of:

1) a system for ensuring the quality of educational activities and the quality of higher education by universities (system of internal quality assurance);

2) system for guaranteeing the quality of educational activities of higher educational institutions and higher education quality;

3) quality assurance system for the activities of the National Agency for Higher Education Quality Assurance and independent institutions for assessing and ensuring the quality of higher education (Law of Ukraine "On Higher Education" dated 28.12.2014).

It should be noted that until recently in Ukraine, the methodology for assessing the quality of educational services was more focused on quantitative indicators. This is the weakness of this technique. If only quantitative indicators are used, the understanding of such a complex object of assessment, which is the quality of education, is depleted [15].

Today Ukraine is following the path of reforms. According to Chapter I, Art. 3, clause 2 of the Law of Ukraine "On Higher Education", the state policy in the field of higher education is based on the principles: promoting sustainable development of society by preparing competitive human 
capital and creating conditions for lifelong learning; international integration and integration of Ukraine's higher education system to the European higher education space, subject to the preservation and development of the achievements and progressive traditions of the national higher education; state support for the training of specialists with higher education for priority sectors of economic activity, areas of fundamental and applied scientific research, scientific and pedagogical activities; promoting the implementation of public-private partnerships in the field of higher education [15].

In Ukraine, the formation and implementation of state policy in the field of higher education is ensured by harmonious interaction of national systems of education, science, business and the state for the sustainable development of the socio-economic development of the state; preservation and development of the higher education system and improving the quality of higher education; development of the autonomy of free economic zones and academic freedom of participants in the educational process; ensuring the development of scientific, scientific-technical and innovative activities of free economic zones and their integration with production; introduction of mechanisms to stimulate enterprises, institutions, organizations of all forms of ownership to provide the first job to graduates. [9].

The principles and procedures for quality assurance in education are defined and legitimized in the documents: Law of Ukraine "On Higher Education" of 28.12.2014 № 1556-VII, "Standards and recommendations for quality assurance in the European higher education space" of the European Association for Quality Assurance in Higher Education, national standard of Ukraine "Quality Management Systems" DSTU ISO 9001: 2009.

Accordingly, the principles of ensuring the quality of education in Ukraine are as follows: compliance with European and national quality standards of higher education; autonomy of the higher education institution, which is responsible for ensuring the quality of educational activities and the quality of higher education; quality monitoring; a systematic approach that involves quality management at all stages of the educational process; constant improvement of the quality of the educational process; involvement of students, employers and other stakeholders in the process of quality assurance in higher education; openness of information at all stages of quality [9].

The National Agency for Higher Education Quality Assurance which operates in Ukraine today, is an independent permanent collegial body and its creation was provided for by the Law of Ukraine "On Higher Education" of 2014.

The National Agency acquires the ability to implement state policy in the field of higher education, to confront modern challenges and to become a catalyst for changes in higher education in Ukraine in order to form a culture of its quality.

The mission of the Agency is to become a catalyst for positive changes in higher education and the formation of a culture of its quality.

The mission of the National Agency for Quality Assurance in Higher Education is to become a catalyst for positive changes in higher education and the formation of a culture of its quality. The strategic goals of the National Agency are implemented in quality of educational services and recognition of the quality of scientific results, The National Agency ensures the systemic impact through: monitoring and analysis of the results of the activities of higher educational institutions to ensure the quality of education through accreditation procedures and certification of scientific personnel; promoting the integration of the higher education system of Ukraine into the global educational and scientific space by establishing partnerships with foreign quality assurance agencies; use of world best practices while respecting the national educational tradition; formation of one's own positive reputation through the trust of participants in the educational process and stakeholders in the Agency. The achievement of these goals is through the implementation of the values and principles of the internal culture of the organization defined by the Agency. In its work, the Agency is guided by the following values: partnership which is the ability to cooperate on the basis of equality, perception of all opinions and respect for existing and potential partners; responsibility which is the ability and willingness to adequately respond to the consequences of actions and decisions; integrity which is commitment to moral principles and standards that meet the principles of professional ethics and personal honesty; transparency which is a willingness to provide the public with complete and objective information about the Agency's system and performance; independence - the ability of the Agency to perform its functions fully and efficiently without external influence; professionalism - the presence of deep competence as a basis for making informed decisions; demanding - a fair desire for professionalism, objectivity and truth; trust - confidence in the decency and friendliness of all participants in the educational process. It should be noted that the Agency adheres to the following principles: respect for everyone's opinion, collegiality, the desire for consensus; the desire for self-improvement, self-development based on critical self-esteem; cultivating a spirit of mutual support, sincerity and initiative; formation and maintenance of institutional and personal reputation.

Conclusions. The systems of higher education quality evaluation in France and in Ukraine are guided, among other things, by the needs and expectations of students, all relevant stakeholders and society. The French system for evaluation of higher education quality has a much older history, and it consists of several specialized institutions which carry out evaluation depending on the type of higher education establishment. The Ukrainian system for assessing the quality of higher education is still at the stage of formation, and will be studied in further publications.

\section{REFERENCES}

1. [Archives] Inspection générale de l'administration de l'éducation nationale et de la recherche (I.G.A.E.N.R.). Retrieved on December 8, 2020 from https://www.enseignementsup-recherche.gouv.fr/cid20300/mission-et-organisation-de-1

i.g.a.e.n.r.html\#: :text=la\%20recherche $\% 20$ (I.G.A.E.N.R.),L'inspection $\% 20 \mathrm{~g} \% \mathrm{C} 3 \% \mathrm{~A} 9 \mathrm{n} \% \mathrm{C} 3 \% \mathrm{~A} 9$ rale $\% 20 \mathrm{de} \% 201$ 'administration $\% 20 \mathrm{de} \% 201 \% \mathrm{C} 3 \%$ A9ducation,sup\%C3\%A9rieur\%20et\%20de\%20la\%20recherche.

2. Bielova L. O. (2016). Yakisna osvita yak zaporuka yakosti zhyttia naselennia (Quality education as a guarantee of quality 
of life). Teoriia ta praktyka derzhavnoho upravlinnia: zb. nauk. pr. Kharkiv: Vyd-vo KharRI NADU "Mahistr", 2016. Issue. 4 (54). p. 8-17.

3. Colet R, N. (2009). L'évaluation de l'enseignement au cœur des processus d'assurance qualité : l'arbre qui cache la forêt. Dans M. Romainville \& C. Coggi (dir.), L'évaluation de l'enseignement par les étudiants (p. 235-253). Louvain-laNeuve : De Boeck Supérieur «Perspectives en éducation et formation».

4. Commission d'évaluation des formations et diplômes de gestion. Accueil. Retrieved on December 8, 2020 from https://www.cefdg.fr/

5. Durdas A. (2020). Assessment of higher education quality: models, principles and approaches. Znanstvena misel journal, Ljubljana, Slovenia, №41/2020, p.33-37

6. Durdas A. (2020). Development of French higher education: current trends. Conference proceedings. International scientific and practical conference "Psychology and pedagogy: current issues", April 10-11, 2020, Kharkiv.

7. Durdas A., Batechko N., (2020). The French model for assessing the quality of higher education: current trends. Continuing Professional Education: Theory and Practice (Series: Pedagogical sciences), No 1, p. 93-98

8. Endrizzi, L. (2014). La qualité de l'enseignement : un engagement des établissements, avec les étudiants? Dossier de veille de l'IFE, (93), 1-44).

9. Gordiychuk S. (2016). Stvorennia standartiv novoho pokolinnia u zabezpechenni yakosti medychnoi osvity (Creation of standards of the new generation in ensuring the quality of medical education). Continuing professional education: theory and practice, Issue 1-2. - p. 121-126
10. Hénard, F. (2010). Learning our lesson. Review of Quality teaching education: Policies and Practises. Paris : OCDE.

11. Histoire et missions de la CTI. Retrieved on December 8, 2020 from https://www.cti-commission.fr/la-cti/histoire-et-missions

12. Kananykina Ye.S. (2013). Sy`stema franczuzskogo vysshego obrazovany`ya (French higher education system). Administrativnoye pravo i praktika administrirovaniya, Issue 8, p. 57 - 81.

13. Kharkivska A. A. Porivnyalnyj analiz osvitnih standartiv deyakyh krayin Yevropy (Comparative analysis of educational standards in some European countries). Retrieved on November $25, \quad 2020$ from: http://www.sportpedagogy.org.ua/html/journal/2008-12/08khasec.pdf

14. Overview of the Quality Assurance System in Higher Education: France. Second edition (2017). National Institution for Academic Degrees and Quality Enhancement of Higher Education. Kodaira, Tokyo, 62 p. URL: https://www.niad.ac.jp/n_kokusai/info/france/overview_fr2_e .pdf

15. Strategy of the National Agency for Quality Assurance of Higher Education until 2022. Retrieved on January 21, 2021 from

https://naqa.gov.ua/\%d0\%bc\%d1\%96\%d1\%81\%d1\%96\%d1 $\% 8 \mathrm{f}-\% \mathrm{~d} 1 \% 82 \% \mathrm{~d} 0 \% \mathrm{~b} 0$

$\% \mathrm{~d} 1 \% 81 \% \mathrm{~d} 1 \% 82 \% \mathrm{~d} 1 \% 80 \% \mathrm{~d} 0 \% \mathrm{~b} 0 \% \mathrm{~d} 1 \% 82 \% \mathrm{~d} 0 \% \mathrm{~b} 5 \% \mathrm{~d} 0 \%$ b3\%d1\%96\%d1\%8f-

$\%$ d0\%b0\%d0\%b3\%d0\%b5\%d0\%bd\%d1\%82\%d1\%81\%d1\% $82 \% \mathrm{~d} 0 \% \mathrm{~b} 2 \% \mathrm{~d} 0 \% \mathrm{~b} 0 /$

16. Stumpf A., Garessus P.-A. (2017). Comment évaluer la qualité d'une formation pour l'améliorer? Ripes : Revue internationale de pédagogie de l'enseignement supérieur, vol. $33, \mathrm{n}^{\circ} 1$. 